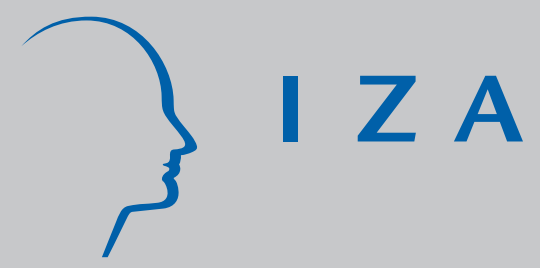

IZA DP No. 774

Labor Market Segmentation and the Earnings of German Guestworkers

Amelie Constant

Douglas S. Massey

May 2003 


\title{
Labor Market Segmentation and the Earnings of German Guestworkers
}

\author{
Amelie Constant \\ University of Pennsylvania and IZA Bonn \\ Douglas S. Massey \\ University of Pennsylvania
}
Discussion Paper No. 774
May 2003

\author{
IZA \\ P.O. Box 7240 \\ D-53072 Bonn \\ Germany \\ Tel.: +49-228-3894-0 \\ Fax: +49-228-3894-210 \\ Email: iza@iza.org
}

\begin{abstract}
This Discussion Paper is issued within the framework of IZA's research area Mobility and Flexibility of Labor. Any opinions expressed here are those of the author(s) and not those of the institute. Research disseminated by IZA may include views on policy, but the institute itself takes no institutional policy positions.
\end{abstract}

The Institute for the Study of Labor (IZA) in Bonn is a local and virtual international research center and a place of communication between science, politics and business. IZA is an independent, nonprofit limited liability company (Gesellschaft mit beschränkter Haftung) supported by the Deutsche Post AG. The center is associated with the University of Bonn and offers a stimulating research environment through its research networks, research support, and visitors and doctoral programs. IZA engages in (i) original and internationally competitive research in all fields of labor economics, (ii) development of policy concepts, and (iii) dissemination of research results and concepts to the interested public. The current research program deals with (1) mobility and flexibility of labor, (2) internationalization of labor markets, (3) welfare state and labor market, (4) labor markets in transition countries, (5) the future of labor, (6) evaluation of labor market policies and projects and (7) general labor economics.

IZA Discussion Papers often represent preliminary work and are circulated to encourage discussion. Citation of such a paper should account for its provisional character. A revised version may be available on the IZA website (www.iza.org) or directly from the author. 


\section{ABSTRACT}

\section{Labor Market Segmentation and the Earnings of German Guestworkers*}

In this paper we study the occupational progress and earnings attainment of immigrants in Germany over time and compare them to native Germans. Our analysis is guided by the human capital and segmented labor market theories. To assess the separate effects of occupational segmentation and discrimination in the allocation of occupations and wages we conceptualize the process of earnings attainment as occurring in three stages: initial occupational achievement, final occupational achievement after the accumulation of experience, and contingent on the former, final earnings attainment. Using data from the German Socioeconomic Panel, our results indicate a high degree of initial occupational segmentation, with immigrants being less able to translate their human capital into a good first job and being channeled into first occupations of significantly lower status than natives. We also developed evidence to suggest that immigrants experienced significant discrimination in the process of occupational attainment, yielding little job mobility over time, and widening the status gap between Germans and guestworkers. Holding occupational status constant, however, we found less evidence of direct discrimination in the process of earnings attainment. Although immigrants achieved lower rates of return to technical or vocational training than natives, their wage returns to experience, hours worked, years since migration, and academic high school were greater, yielding significant earnings mobility over time.

JEL Classification: J2, J3, J4, J6, J7

Keywords: occupational achievement, earnings assimilation, human capital, labor market segmentation, international migration

Corresponding author:

Amelie Constant

Population Studies Center

University of Pennsylvania

3718 Locust Walk

Philadelphia, PA 19104-6298

Email: aconstan@pop.upenn.edu

\footnotetext{
* This study has been made possible through various research visits to DIW Berlin and IZA in Bonn. We are grateful for the access to the data, and useful comments by Klaus F. Zimmermann.
} 


\section{INTRODUCTION}

It is well documented that foreign workers earn less than natives in the German labor market (Velling 1995; Constant 1998). Various attempts have been made to determine empirically whether these earnings differentials reflect underlying differences in human capital or ethnic discrimination in the labor market. Both effects may be expressed at either of two stages in the earnings process: in the allocation of people to occupations or in the assignment of earnings to people within occupational groups. Given that most foreigners originally entered Germany as "guests" to occupy low status jobs that natives avoided, it is not surprising that the country's occupational distribution was initially characterized by a high degree of ethnic stratification(Hoffman-Nowotny 1973; Marsden 1990; Heckmann 1992).

Over time, however, occupational sorting based on human capital occurred, and recent research suggests that both the allocation of persons to occupations and the determination of earnings within occupational groups are determined mainly by human capital characteristics (Velling 1995; Muller, Steinmann, and Ell 1998; Kalter and Granato 2002). Most of this work has employed crosssectional data and methods, however. In this paper we revisit the issues of discrimination and labor market segmentation using a dynamic model that traces the occupational progress of immigrants over time.

\section{THEORETICAL MODEL}

Our analysis of occupational achievement and earnings attainment is guided by two competing theoretical perspectives: human capital theory and segmented labor market theory. Figure 1 presents a graphic representation of our model. Following human capital theory (Becker 1975), we assume that immigrants and natives both enter the German labor market and endeavor to 
convert their human capital attainments into the highest possible initial occupational status. Over time we then expect both natives and foreigners to attempt to maximize the returns to human capital by seeking better jobs, yielding an increase in occupational status over time. During the last year of observation, we measure earnings, which we assumed to be determined by human capital characteristics and conditioned on prior occupational achievement.

\section{FIGURE 1 ABOUT HERE}

In the first stage of the attainment process, we expect to observe significant ethnic stratification by occupation as predicted by segmented labor market theory (Piore 1979). Migrant workers were recruited into Germany to take unskilled and semi-skilled jobs shunned by natives (Payne 1974; Heckmann 1992). Without this infusion of foreign labor, Germany's postwar economic boom could not have continued (Kindleberger 1969). The initial segmentation between immigrants and natives in the German labor market is then subsequently reinforced by the tight link between education, training, and jobs characteristic of the labor market (Muller, Steinmann, and Ell 1998). Ethnic segmentation is observed as systematic difference in the status of initial occupations between natives and guestworkers adjusting for human capital characteristics.

As guestworkers prolong their stay in Germany, however, they acquire increasing amounts of country-specific human capital and undertake occupational mobility. If the mobility process continues to be segmented along ethnic lines, however, we will observe the persistence of significant native-foreign differentials in occupational status, and if foreigners are discriminated against in Germany's labor market, we will witness lower rates of conversion between human capital and occupational prestige. 
Persistent ethnic segmentation in employment and past discrimination in hiring will produce an ongoing gap in occupational status that will translate into differential earnings between natives and foreigners. Holding occupational status constant, we may also observe direct wage discrimination, which would be indicated by immigrants receiving systematically lower wage returns to human capital and occupational status than Germans. Although lower returns to human capital are consistent with a process of wage discrimination, however, they do not constitute proof, as the differential may also reflect the influence of unmeasured variables not included in the wage regression.

\section{DATA AND METHODS}

Our data come from the German Socioeconomic Panel (GSOEP), a nationally representative longitudinal survey administered by the German Economic Institute (DIW). It was launched in 1984 in the Federal Republic of Germany (West Germany) with about 12,000 respondents, some 3,000 of whom were legal immigrants. The original cohort included persons from Italy, Greece, Spain, Yugoslavia, and Turkey, the principal sources of guestworker migration prior to 1973. The first wave covered only non-institutionalized respondents, but if members of the original panel were later institutionalized they were followed and kept in the survey.

Each year the GSOEP interviews members of baseline households who are 16 or older at the survey date. Thus, the panel expands over time as children within households of the original panel grow up and turn 16. The most important feature of the GSOEP from our viewpoint is that it oversamples immigrants and provides data on certain of their pre-migration characteristics (SOEP Group 2001). From the 1984-1997 waves of the survey we selected all persons aged 16 or older who were 
ever employed during any of the 14 waves, yielding wage and occupational data on 4,318 guestworkers and 11,135 Germans.

Unfortunately, the GSOEP does not allow us to observe a respondent's first job in the labor market. Except for those who turned 16 after the panel's inception, we only observe the status of the occupation they held during the first year of the survey in 1984. Likewise, final occupational status is not that of the last occupation held by respondents unless they retired between 1984 and 1997. For most respondents the final occupational status is that observed during the last wave of the panel survey (or the last year of employment if they were jobless in 1997).

We measure human capital using a variety of indicators available from the GSOEP. Naturally, we consider the effects of formal schooling in Germany, dividing the sample into mutually exclusive education groups based on the level of education completed. We also measure whether the respondent received additional vocational training in Germany and the number of years of schooling that immigrants completed before arrival. Experience is measured in terms of age, years since migration, and the amount of time between first and last jobs. Finally, we include a dichotomous indicator of whether foreign respondents were fluent in German.

In seeking to measure the effects of human capital on occupational status and earnings we control for basic socio-demographic characteristics such as gender, marital status, the presence of children, and home ownership. Among immigrants we also hold constant the effects of nationality, birthplace, naturalization of children, and whether or not the respondent "feels German" (indicating a strong sentimental attachment to the host country) and whether or not that person had ever remitted funds abroad (indicating a strong behavioral connection to the homeland). Earnings are measured in terms of weekly wages (in nominal German Marks) earned by respondents and occupational status 
is assessed using the international SEI score developed by Trieman (1977) and updated by Ganzeboom, de Graaf, and Treiman (1992), which is itself an internationally-normed version of a scale developed originally by (Duncan 1961).

Table 1 presents means and standard deviations for the above variables tabulated separately for Germans and guestworkers. As expected, there are significant gaps in occupational status and earnings between the two groups. Across person-years observed in the panel, the average foreigner held an occupation that provided 33.2 prestige points and $435 \mathrm{DM}$ per week in wages, whereas the typical German earned 38.2 prestige points and 501 DM per week. No doubt some of these gaps stem from the obvious differences in human capital between immigrants and natives. Whereas $90 \%$ of foreigners had secondary schooling or less, the figure was only $64 \%$ for Germans, and whereas $26 \%$ of Germans had attended a technical high school and $10 \%$ had finished academic high school, only $9 \%$ and $1 \%$ of foreigners had done so, respectively. Likewise, $61 \%$ of natives had received German vocational training, compared with $16 \%$ of foreigners. In terms of experience, the average immigrant was some 8 years younger than the typical German (31.5 versus 39.6 years of age), though immigrants had been in Germany for an average of around 14 years.

About half of respondents in both groups were male, but immigrants were somewhat more likely to be married. Whereas only $53 \%$ of Germans were currently married, $61 \%$ of foreigners were in this state (58\% with a spouse in Germany, $3 \%$ with a spouse at home). Immigrants were also far more likely to have children present in the household, with $61 \%$ reporting children at home compared with just $36 \%$ of Germans. Natives, however, were far more likely than foreigners to be homeowners. Nearly half of all Germans owned their home (47\%) compared with just $7 \%$ of immigrants. 
Despite having spent an average of 14 years in Germany, the vast majority of immigrants had not attained fluency in the German language: only $20 \%$ reported themselves as fluent in German. Interestingly, the percentage born in Germany was also $20 \%$, suggesting that true fluency comes primarily from growing up in that country. Despite the fact that a fifth of foreign respondents were born in Germany, only $4 \%$ said they "felt German" whereas $22 \%$ reported remitting money to family members overseas. Only $16 \%$ of foreigners had attained German nationality, and only $7 \%$ reported having naturalized their children. Some $35 \%$ of immigrants held citizenship in another country of the European Union, 33\% were Turkish, and 16\% were Yugoslav. In general, these immigrantspecific measures do not suggest a high degree of integration within German society or the labor market.

\section{DETERMINANTS OF INITIAL OCCUPATIONAL STATUS}

Table 2 shows coefficients of two OLS equations estimated to predict the status of the occupation that Germans and foreign workers held when the GSOEP began in 1984 (or when they took their first job thereafter). The coefficients represent the number of prestige points generated by a unit change on the independent variable in question. As can be seen, foreigners generally experienced fewer status returns per unit of human capital on their initial occupation. Whereas completing a technical high school garnered Germans 5.7 additional prestige points, it got foreigners a mere 1.2 points (a difference that is statistically significant at $\mathrm{p}<.05$ ). Likewise, completing academic high school (Abitur) earned Germans around 12.9 prestige points on first occupation, compared with just 6 points for foreigners (again significant at $\mathrm{p}<.05$ ). The relative rates of return to vocational training were somewhat closer but at 9.2 versus 6.6 , but the rate for Germans was still significantly greater $(\mathrm{p}<.05)$. Foreigners did, however, earn a 1.3 point status premium for being 
fluent in German, and both groups experienced about the same returns from aging: around 0.09 points per year.

\section{TABLE 2 ABOUT HERE}

Among control variables, foreign males held jobs that were of significantly lower status compared with foreign females, a gender differential that did not exist among natives. Both immigrants and natives experienced a marriage premium, but the boost was greater for guestworkers than Germans. Whereas being married increased occupational status by 4.7 points among natives, the premium was 8.6 points for immigrants with spouses in Germany and 5.3 points for those with spouses abroad. As one might expect, immigrants who had achieved German citizenship held occupations that were more prestigious (by 1.6 points) than those who did not, but surprisingly, foreign nationals who were born in Germany actually held jobs that were less prestigious than other foreigners (by 2.7 points). The latter finding suggests that ethnic segmentation in the labor force may, in fact, widen in the second generation.

The general impression left by the estimates in Table 2 is that immigrants are initially less able than natives to translate their human capital into occupational status within the German labor market. Results indicate that guestworkers experience significantly lower returns to education and vocational training than Germans, and the curvilinear relationship between years since migration and occupational status suggest that immigrants take on very low status jobs when they arrive and that they remain in these jobs for some time before moving upward. 


\section{DETERMINANTS OF STATUS ON LAST OCCUPATION}

In Table 3 we show estimates for two equations predicting status achieved in the final occupation held by natives and foreigners (either the job held in the final year of the panel or that held in the last year of employment). Both models are estimated controlling for the status earned on the respondent's initial occupation. As can be seen, beginning occupational status plays a very strong role in determining the final occupational status achieved by both groups. Among Germans, each status point in the initial occupation yields 0.54 points on the final occupation. Among guestworkers, each initial status point yields 0.51 points on the final occupation slightly but significantly lower than the rate observed for natives.

\section{TABLE 3 ABOUT HERE}

Whatever the constraints imposed by the initial job on the final status achieved, Germans are far better able to use their human capital to attain occupational mobility than guestworkers. Whereas completing technical high school brought a 2.6-point status boost for natives, it yielded nothing for foreigners; and whereas achievement of an abitur yielded a 9-point gain for Germans, the net benefit was only 4.5 points for guestworkers. But perhaps the most startling differences in the returns to experience, which we measure as the time elapsed between the first and last job. Whereas each year of additional labor market experience yields 0.237 points of occupational status for Germans, it brings just a 0.067 increase for guestworkers. Moreover, we detect no significant effect of years between migration and first job in determining the final occupational status of foreigners. Finally, though having fluency in German does increase the final occupational status of immigrants by 2.1 points, no other immigrant-related variables are apparently influential in the process of occupational mobility; and demographic controls generally operate to the disadvantage of foreigners. 
In Figure 2 we contrast the process of occupational mobility experienced by natives and foreigners employed in the German labor market by comparing the experience of two hypothetical workers, one German and one immigrant. We assume that the German worker enters the labor market at age 20 with average characteristics for natives and then plot the occupational status achieved as the person ages and accumulates experience over the next 20 years. We likewise assume that the immigrant arrives in Germany at age 20 to take a first job with the average characteristics of foreigners and then plot the occupational status achieved as the person ages and accumulates experience over the same period of time.

\section{FIGURE 2 ABOUT HERE}

This graph makes clear the severe handicap faced by guestworkers in the German labor market. Given lower skills and education and lower returns to this human capital, immigrants begin the process of occupational attainment with a four-point prestige gap compared with their native counterparts. Thereafter small returns to job experience (just .067 points per year) are offset by the negative effects of aging (-.071 points per year) to bring about a stagnation in the occupational status of immigrants, yielding a flat profile and no occupational mobility. In contrast, because they enjoy higher skills and education than foreigners, as well as higher rates of returns to such human capital, German workers enter the labor force at a higher level and thereafter experience considerable mobility, as the returns to experience (.237 points per year) greatly outweigh the negative effects of aging (also -.071 per year). As a result, the prestige gap between natives and foreigners widens over time. 


\section{DETERMINANTS OF WEEKLY EARNINGS}

In Table 4 we consider the effect that initial ethnic segmentation and discrimination in the process of occupational attainment affect the final weekly earnings achieved by Germans and guestworkers. Although foreigners achieve a much higher rate of return for the completion of academic high school than natives, recall that $99 \%$ of the guestworkers in the sample do not attain this level of education. In contrast, the rates of return to the completion of technical high school and vocational training, more realistic goals for most immigrants, are far lower among guestworkers than among Germans. Whereas natives earned a wage premium of $4 \%$ for finishing technical high school and $45 \%$ for having additional vocational training, the respective figures for foreigners were $1 \%$ and $11 \%$.

\section{TABLE 4 ABOUT HERE}

Among immigrants, however, final occupational status was less of a drag on earnings than among natives, while the returns to hours worked and time since first job were significantly greater, indicating a significant process of immigrant earnings mobility over time. Whereas each prestige point only lowered earnings by $0.8 \%$ among foreigners (compared with $1.4 \%$ among natives), each additional hour worked yielded $2.4 \%$ more earnings and each additional year of work experience since the first job boosted weekly wages by $4.5 \%$ (compared with respective figures of $1.1 \%$ and $1.3 \%$ for natives). Wages for immigrants also increase with years since arrival, although at a decreasing rate. The only experience indicator favoring Germans is age, where their coefficient of .008 is significantly greater than the figure of .003 for guestworkers.

Among control variables, males earn higher wages than females (though the gender premium is greater for German than immigrant men). Foreigners also experience roughly a $20 \%$ marriage 
premium compared with nothing for natives. Paradoxically, immigrants have achieved German citizenship earned $12 \%$ less than those who had not, whereas those who displayed a strong behavior connection to the home country (by remitting) earned 6\% higher wages.

The evidence presented to this point suggest a significant degree of ethnic segmentation upon entry into the German labor market, combined with some ethnic discrimination in the allocation of people to jobs thereafter, but no evidence of ethnic discrimination in the setting of wages within occupations of similar status. If anything, immigrants appear to experience higher rates of earnings mobility than natives as they accumulate time in the German labor market. Thus, whereas the existence of a significant status gap upon entry, when combined with a general lack of occupational mobility over time and a lack of returns to technical education or vocational training, imply an ongoing gap between Germans and guestworkers with respect to earnings, the generally high returns to experience enjoyed by the latter suggests that at some point in an immigrant's career the earnings gap might be overcome, as has been observed among immigrant workers in the United States.

Figure 3 plots predicted weekly wages for immigrants and natives by time accumulated in the labor force since the first job. As before, we assume that an immigrant with average characteristics arrives at age 20 to take a first job in Germany and then increases his or her age, experience, and time since arrival by one year each year thereafter. We likewise assume that a German with average characteristics enters gets a first job at age 20 and then increases his or her age and experience annually by one year for the next 30 years.

\section{FIGURE 3 ABOUT HERE}

As expected, the immigrants start at a serious earnings disadvantage, reflecting prior ethnic segmentation and discrimination in occupational attainment, as well as lower levels of education and 
training and lower returns to human capital in the earnings attainment process. Over time, however, the earnings of both workers rise, but those of immigrants rise at a faster rate, finally reaching parity at around 23 years. Thereafter the earnings of immigrants exceed those of German natives, other things equal.

\section{CONCLUSION}

In this analysis we considered the relative position of immigrants and natives in the German labor market. In order to assess the separate effects of occupational segmentation and discrimination in the allocation of occupations and wages we conceptualized the process of earnings attainment as occurring in three stages: initial occupational achievement, final occupational achievement after the accumulation of experience, and contingent on the former, final earnings attainment. We specified this model in terms of three equations, one predicting first occupational, another predicting last occupation, and the last predicting earnings. We then estimated the three equations using data from the German Socioeconomic Panel, operationalizing first job as occupational status observed in the survey's first year, last job as occupational status observed in the survey's final year, and earnings as weekly wages reported for the final year.

Our results indicated a high degree of initial occupational segmentation, with immigrants being less able to translate their human capital into a good first job and being channeled into first occupations of significantly lower status than natives. We also developed evidence to suggest that immigrants experienced significant discrimination in the process of occupational attainment, yielding little job mobility over time. If anything, the status gap between Germans and guestworkers widened with time spent in the labor market. 
Holding occupational status constant, however, we found less evidence of direct discrimination in the process of earnings attainment. Although immigrants achieved lower rates of return to technical or vocational training than natives, their wage returns to experience, hours worked, years since migration, and academic high school were greater, yielding significant earnings mobility over time. The rates of return to experience are such that immigrants reach parity with natives after about 23 years in the German labor market.

If economic conditions are to improve for guestworkers in Germany, therefore, policies must focus on education and the connection between education and occupation rather than on combating wage discrimination in the labor market itself. Very few people of foreign nationality complete academic high school in Germany, despite the large payoffs in terms of both occupational status and wages, and greater educational achievement would significantly boost the economic status of foreigners, particularly in the second generation. But improved education by itself will not be enough unless concrete steps are taken to equalize access to initial prestige jobs and to ensure fairer access to the ladders of occupational mobility within the German labor market, where natives enjoy systematic advantages with respect to status and mobility that are unexplained by background differences with respect to human capital or other personal characteristics. 


\section{REFERENCES}

Becker, Gary S. 1975. Human Capital: A Theoretical and Empirical Analysis, $2^{\text {nd }}$ Edition. New York: Columbia University Press.

Duncan, Otis Dudley. 1961. “A Socioeconomic Index for All Occupations.” In Albert J. Reiss, Otis Dudley Duncan, Paul K. Hatt, and Cecil C. North, eds., Occupations and Social Status. New York: Free Press.

Constant, Amelie.. 1998. The Earnings of Male and Female Guestworkers and Their Assimilation into the German Labor Market: A Panel Study 1984-1993. Ph.D. Dissertation, Vanderbilt University.

Ganzeboom, Harry B.G., Paul De Graaf, and Donald J. Treiman. 1992. “A Standard

International Socio-Economic Index of Occupational Status.” Social Science Research 21:1-56.

Heckmann, Friedrich. 1992. Ethnische Minderheiten, Vol und Nation. Soziologie InterEthnischer Beziehungen. Stuttgart: Enke.

Hoffman-Nowotny, Hans-JOachim. 1973. Soziologie des Fremdarbeiterproblems: Eine Theoretische und Empirische Analyse am Beispiel der Schweiz. StuttgartL Enke.

Kalter, Frank, and Nadia Granato. 2002. “Ethnic Minorities' Education and Occupational Attainment: The Case of Germany. Paper presented at the Meeting of Research Committee 28 of the International Sociological Association, Oxford, April 10-13.

Kindleberger, Charles P. 1967. Europe's Postwar Growth: The Role of Labor Supply. Cambridge: Harvard University Press.

Marsden, David. 1990. "Institutions and Labour Mobility: Occupational and Internal Labour 
Markets in Britain, France, Italy, and West Germany.” Pp. xx-xx in Renato Brunetta and Carlo Dell'Aringa, eds., Labour Relations and Economic Performance. New York: New York University Press.

Müller, Walter, Susanne Steinmann, and Renate Ell. 1998. "Education and Labour-Market Entry in Germany.” Pp. 143-88 in Yossi Shavit and Walter Müller, eds., From School to Work: A Comparative Study of Educational Qualifications and Occupational Destinations. Oxford: Oxford University Press.

Paine, Suzanne. 1974. Exporting Workers: The Turkish Case. Cambridge: Cambridge University Press.

Piore, Michael J. 1979. Birds of Passage: Migrant Labor in Industrial Societies. New York: Cambridge University Press.

SOEP Group (2001) The German Socio-Economic Panel (GSOEP) after more than 15 years Overview. In: Elke Host, Dean R. Lillard, and Thomas A DiPrete (eds): Proceedings of the 2000 Fourth International Conferences of German Socio-Economic Panel Study Users (GSOEP2000), Quarterly Journal of Economic Research, Vol. 70, No. 1, 7-14.

Treiman, Donald J. 1977. Occupational Prestige in Comparative Perspective. New York: Academic Press.

Velling, Johannes. 1995. Wage Discrimination and Occupational Segregation of Foreign Male Workers in Germany. Discussion Paper No. 95-04. Zentrum für Europäische Wirtschaftsforschung, Mannheim Universität.

Zimmermann, Klaus F. 1999 “German Job Mobility and Wages,” IZA Reprint Series A - 1. 
Table 1. Means and standard deviations for variables used in analysis of variables used in analysis of occupational and earnings attainment in Germany.

\begin{tabular}{|c|c|c|c|c|}
\hline \multirow[b]{2}{*}{ Variable } & \multicolumn{2}{|c|}{ Germans } & \multicolumn{2}{|c|}{ Guestworkers } \\
\hline & Mean & $\begin{array}{l}\text { Standard } \\
\text { Deviation }\end{array}$ & Mean & $\begin{array}{l}\text { Standard } \\
\text { Deviation }\end{array}$ \\
\hline \multicolumn{5}{|l|}{ OUTCOME MEASURES } \\
\hline Occupational Prestige & 38.24 & 13.52 & 33.17 & 10.75 \\
\hline Weekly Earnings (DM) & 501.42 & 648.18 & 435.54 & 474.30 \\
\hline \multicolumn{5}{|l|}{ HUMAN CAPITAL } \\
\hline \multicolumn{5}{|l|}{ Formal Schooling in Germany } \\
\hline Secondary or Less & 0.64 & 0.48 & 0.90 & 0.40 \\
\hline Technical-Other & 0.26 & 0.44 & 0.09 & 0.28 \\
\hline Abitur or Greater & 0.10 & 0.30 & 0.01 & 0.09 \\
\hline \multicolumn{5}{|l|}{ Other Education } \\
\hline German Vocational Training & 0.61 & 0.49 & 0.16 & 0.37 \\
\hline Years of Foreign Schooling & ---- & ---- & 4.51 & 3.57 \\
\hline \multicolumn{5}{|l|}{ Experience } \\
\hline Age & 39.64 & 18.78 & 31.53 & 13.27 \\
\hline Years Since Migration & ---- & ---- & 14.27 & 7.53 \\
\hline \multicolumn{5}{|l|}{ Language Ability } \\
\hline Speak Fluent German & ---- & ---- & 0.20 & 0.40 \\
\hline \multicolumn{5}{|l|}{ CONTROL VARIABLES } \\
\hline \multicolumn{5}{|l|}{ Demographic Situation } \\
\hline Male & 0.48 & 0.50 & 0.52 & 0.50 \\
\hline Married-Spouse in Germany & 0.53 & 0.50 & 0.58 & 0.49 \\
\hline Married-Spouse not in Germany & ---- & ---- & 0.03 & 0.17 \\
\hline Children in Household & 0.36 & 0.48 & 0.61 & 0.49 \\
\hline Owns Home & 0.47 & 0.50 & 0.07 & 0.25 \\
\hline \multicolumn{5}{|l|}{ Immigrant Situation } \\
\hline \multicolumn{5}{|l|}{ Nationality } \\
\hline European & ---- & ---- & 0.35 & 0.48 \\
\hline German & ---- & ---- & 0.16 & 0.36 \\
\hline Turk & ---- & ---- & 0.33 & 0.47 \\
\hline Yugoslav & ---- & ---- & 0.16 & 0.37 \\
\hline Born in Germany & ---- & ---- & 0.20 & 0.40 \\
\hline Naturalized Children & ---- & ---- & 0.07 & 0.26 \\
\hline Feel German & ---- & ---- & 0.04 & 0.18 \\
\hline Remits & ---- & ---- & 0.22 & 0.41 \\
\hline
\end{tabular}


Table 2. Regression of occupational prestige during first year in panel on selected predictor variables.

\begin{tabular}{|c|c|c|c|c|}
\hline \multirow[b]{2}{*}{ Variable } & \multicolumn{2}{|c|}{ Germans } & \multicolumn{2}{|c|}{ Guestworkers } \\
\hline & $\mathrm{B}$ & $\mathrm{SE}$ & $\mathrm{B}$ & $\mathrm{SE}$ \\
\hline \multicolumn{5}{|l|}{ HUMAN CAPITAL } \\
\hline \multicolumn{5}{|l|}{ Formal Schooling in Germany } \\
\hline Secondary or Less & ---- & ---- & ---- & ---- \\
\hline Technical-Other & $5.729 * * *$ & 0.240 & $1.191 * * *$ & 0.589 \\
\hline Abitur or Greater & $12.856^{* * *}$ & 0.346 & $5.982 * * *$ & 1.713 \\
\hline \multicolumn{5}{|l|}{ Other Education } \\
\hline German Vocational Training & $9.157 * * *$ & 0.229 & $6.648 * * *$ & 0.446 \\
\hline Years of Foreign Schooling & ---- & ---- & $0.263 * * *$ & 0.058 \\
\hline \multicolumn{5}{|l|}{ Experience } \\
\hline Age & $0.092 * * *$ & 0.006 & $0.096 * * *$ & 0.018 \\
\hline Years Since Migration & ---- & ---- & $-0.321 * * *$ & 0.052 \\
\hline Years Since Migration Squared & ---- & ---- & $0.007 * * *$ & 0.001 \\
\hline \multicolumn{5}{|l|}{ Language Ability } \\
\hline Speak Fluent German & ---- & ---- & $1.434 * * *$ & 0.445 \\
\hline \multicolumn{5}{|l|}{ CONTROL VARIABLES } \\
\hline \multicolumn{5}{|l|}{ Demographic Situation } \\
\hline Male & 0.117 & 0.205 & $-1.865 * * *$ & 0.320 \\
\hline Married-Spouse in Germany & $4.723 * * *$ & 0.235 & $8.640 * * *$ & 0.439 \\
\hline Married-Spouse not in Germany & ----- & ---- & $5.315 * * *$ & 1.038 \\
\hline Children in Household & $0.661 * *$ & 0.228 & -0.500 & 0.336 \\
\hline Owns Home & -0.006 & 0.204 & 0.766 & 0.615 \\
\hline \multicolumn{5}{|l|}{ Immigrant Situation } \\
\hline \multicolumn{5}{|l|}{ Nationality } \\
\hline European & ---- & ---- & ---- & ---- \\
\hline German & ---- & ---- & $1.613^{*}$ & 0.733 \\
\hline Turk & ---- & ---- & 0.265 & 0.392 \\
\hline Yugoslav & ---- & ---- & -0.177 & 0.470 \\
\hline Born in Germany & ---- & ---- & $-2.732 * * *$ & 0.716 \\
\hline Naturalized Children & ---- & ---- & 0.437 & 0.643 \\
\hline Feel German & ---- & ---- & -0.036 & 0.854 \\
\hline Remits & ---- & ---- & -0.589 & 0.427 \\
\hline Intercept & $21.024 * * *$ & 0.329 & $25.288 * * *$ & 0.780 \\
\hline $\mathrm{R}^{2}$ & $0.353 * * *$ & & $0.252 * * *$ & \\
\hline Number of Cases & 11,133 & & 4,318 & \\
\hline
\end{tabular}

$* * * \mathrm{p}<.001 ; \quad * * \mathrm{p}<.01 ; \quad * \mathrm{p}<.05$ 
Table 3. Regression of occupational prestige during last year in panel on selected predictor variables.

\begin{tabular}{|c|c|c|c|c|}
\hline \multirow[b]{2}{*}{ Variable } & \multicolumn{2}{|c|}{ Germans } & \multicolumn{2}{|c|}{ Guestworkers } \\
\hline & $\mathrm{B}$ & SE & $\mathrm{B}$ & SE \\
\hline \multicolumn{5}{|l|}{ HUMAN CAPITAL } \\
\hline \multicolumn{5}{|l|}{ Formal Schooling in Germany } \\
\hline Secondary or Less & ---- & ---- & ---- & --- \\
\hline Technical-Other & $2.588 * * *$ & 0.215 & -0.584 & 0.542 \\
\hline Abitur or Greater & $8.994 * * *$ & 0.319 & $4.523 * *$ & 1.572 \\
\hline \multicolumn{5}{|l|}{ Other Education } \\
\hline German Vocational Training & 0.320 & 0.213 & 0.155 & 0.419 \\
\hline Years of Foreign Education & ---- & ---- & 0.087 & 0.053 \\
\hline \multicolumn{5}{|l|}{ Experience } \\
\hline Initial Occupational Status & $0.540 * * *$ & 0.008 & $0.513 * * *$ & 0.014 \\
\hline Age & $-0.071 * * *$ & 0.006 & $-0.071 * * *$ & 0.017 \\
\hline Time Since First Job & $0.237 * * *$ & 0.018 & $0.067 *$ & 0.029 \\
\hline Years Since Migration & ---- & ---- & -0.048 & 0.048 \\
\hline Years Since Migration Squared & ---- & ---- & 0.001 & 0.001 \\
\hline Language Ability & & & & \\
\hline Speak Fluent German & ---- & ---- & $2.061 * * *$ & 0.409 \\
\hline
\end{tabular}

\section{CONTROL VARIABLES}

\begin{tabular}{|c|c|c|c|c|}
\hline \multicolumn{5}{|l|}{ Demographic Situation } \\
\hline Male & $1.755 * * *$ & 0.179 & 0.515 & 0.294 \\
\hline Married-Spouse in Germany & $-1.716^{* * *}$ & 0.211 & $-1.276^{* * *}$ & 0.416 \\
\hline Married-Spouse not in Germany & ----- & ---- & -1.113 & 0.954 \\
\hline Children in Household & -0.080 & 0.199 & -0.417 & 0.308 \\
\hline Owns Home & $0.740 * * *$ & 0.178 & $1.657 * *$ & 0.564 \\
\hline \multicolumn{5}{|l|}{ Immigrant Situation } \\
\hline \multicolumn{5}{|l|}{ Nationality } \\
\hline European & ---- & ---- & ---- & --- \\
\hline German & ---- & ---- & 0.184 & 0.672 \\
\hline Turk & ---- & ---- & -0.098 & 0.358 \\
\hline Yugoslav & ---- & ---- & 0.236 & 0.432 \\
\hline Born in Germany & ---- & ---- & 0.381 & 0.666 \\
\hline Naturalized Children & ---- & ---- & -0.977 & 0.589 \\
\hline Feel German & --- & ---- & 0.012 & 0.782 \\
\hline Remits & ---- & ---- & -0.413 & 0.392 \\
\hline Intercept & $17.603 * * *$ & 0.358 & 19.047 & 0.808 \\
\hline $\mathrm{R}^{2}$ & $0.466 * * *$ & & $0.280 * * *$ & \\
\hline Number of Cases & 11,026 & & 4,318 & \\
\hline
\end{tabular}

$* * * \mathrm{p}<.001 ; \quad * * \mathrm{p}<.01 ; \quad * \mathrm{p}<.05$ 
Table 4. Regression of log of weekly wages on occupation prestige during last year and selected predictor variables.

\begin{tabular}{|c|c|c|c|c|}
\hline \multirow[b]{2}{*}{ Variable } & \multicolumn{2}{|c|}{ Germans } & \multicolumn{2}{|c|}{ Guestworkers } \\
\hline & $\mathrm{B}$ & SE & $\mathrm{B}$ & SE \\
\hline \multicolumn{5}{|l|}{ HUMAN CAPITAL } \\
\hline \multicolumn{5}{|l|}{ Formal Schooling in Germany } \\
\hline Secondary or Less & ---- & ---- & ---- & ---- \\
\hline Technical-Other & $0.040 *$ & 0.018 & 0.010 & 0.029 \\
\hline Abitur or Greater & 0.019 & 0.025 & $0.233 * * *$ & 0.073 \\
\hline \multicolumn{5}{|l|}{ Other Education } \\
\hline German Vocational Training & $0.451 * * *$ & 0.021 & $0.108 * * *$ & 0.024 \\
\hline Years of Foreign Schooling & ---- & ---- & 0.007 & 0.004 \\
\hline \multicolumn{5}{|l|}{ Experience } \\
\hline Hours Worked & $0.011 * * *$ & 0.0005 & $0.024 * * *$ & 0.001 \\
\hline Last Occupational Status & $0.014 * * *$ & 0.0008 & $0.008 * * *$ & 0.001 \\
\hline Age & $0.008 * * *$ & 0.001 & $0.003 *$ & 0.001 \\
\hline Time Since First Job & $0.013 * * *$ & 0.002 & $0.045 * * *$ & 0.002 \\
\hline Years Since Migration & ---- & ---- & $0.010 *$ & 0.004 \\
\hline Years Since Migration Squared & ---- & ---- & $-0.0002 *$ & 0.0001 \\
\hline \multicolumn{5}{|l|}{ Language Ability } \\
\hline Speak Fluent German & ---- & ---- & 0.025 & 0.027 \\
\hline \multicolumn{5}{|l|}{ CONTROL VARIABLES } \\
\hline \multicolumn{5}{|l|}{ Demographic Situation } \\
\hline Male & $0.476^{* * *}$ & 0.016 & $0.249 * * *$ & 0.021 \\
\hline Married-Spouse in Germany & 0.030 & 0.020 & $0.200 * * *$ & 0.026 \\
\hline Married-Spouse not in Germany & ----- & ---- & $0.176^{* *}$ & 0.063 \\
\hline Children in Household & -0.031 & 0.018 & -0.024 & 0.021 \\
\hline Owns Home & $-0.059 * *$ & 0.016 & 0.001 & 0.028 \\
\hline \multicolumn{5}{|l|}{ Immigrant Situation } \\
\hline \multicolumn{5}{|l|}{ Nationality } \\
\hline European & ---- & ---- & ---- & ---- \\
\hline German & ---- & ---- & $-0.121 * *$ & 0.036 \\
\hline Turk & ---- & ---- & -0.011 & 0.024 \\
\hline Yugoslav & ---- & ---- & -0.014 & 0.028 \\
\hline Born in Germany & ---- & ---- & 0.038 & 0.037 \\
\hline Naturalized Children & ---- & ---- & 0.066 & 0.047 \\
\hline Feel German & ---- & --- & -0.011 & 0.048 \\
\hline Remits & ---- & ---- & $0.060 * *$ & 0.024 \\
\hline Intercept & $4.792 * * *$ & 0.048 & $4.354 * * *$ & 0.074 \\
\hline $\mathrm{R}^{2}$ & $0.428 * * *$ & & $0.470 * * *$ & \\
\hline Number of Cases & 5,970 & & 2,515 & \\
\hline
\end{tabular}

$* * * \mathrm{p}<.001 ; \quad * * \mathrm{p}<.01 ; \quad * \mathrm{p}<.05$ 
Figure 1

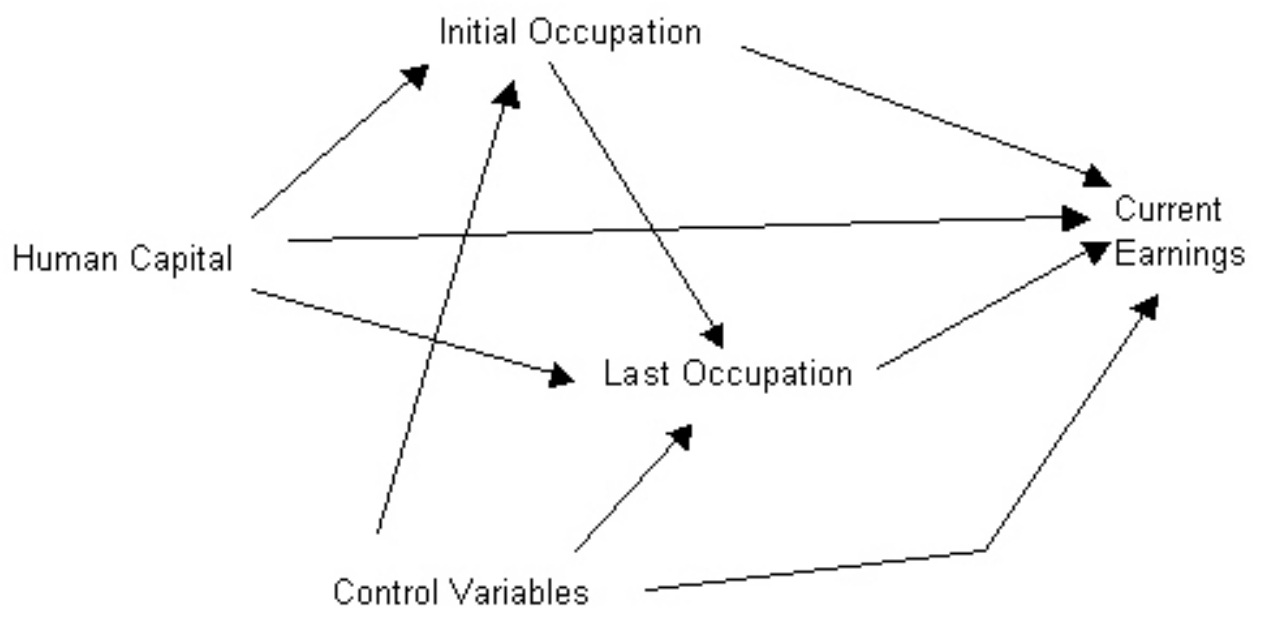


Figure 2. Predicted occupational mobility for hypothetical German and foreign worker

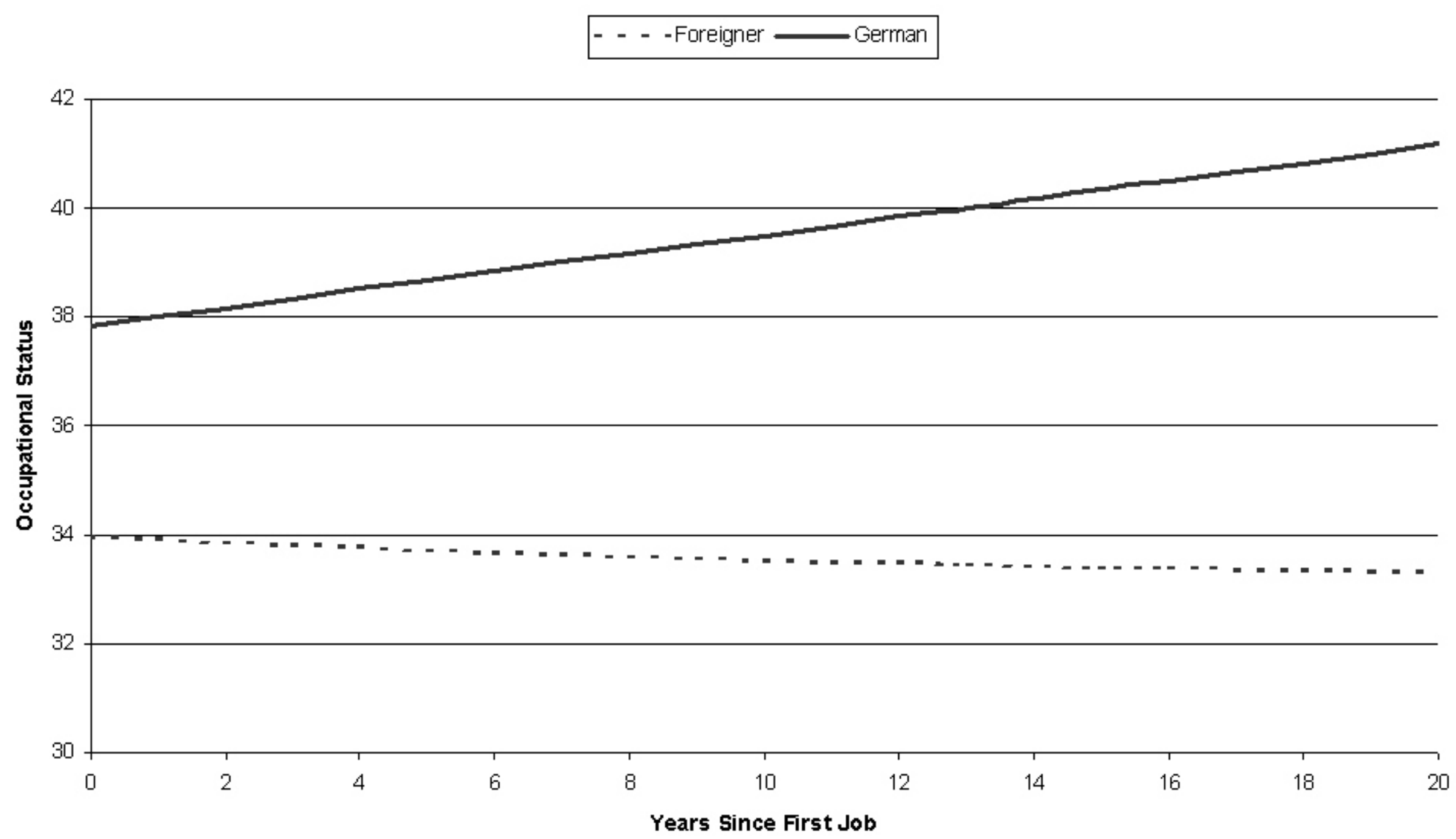


Figure 3. Predicted weekly wages earned by hypothetical German and foreign worker.

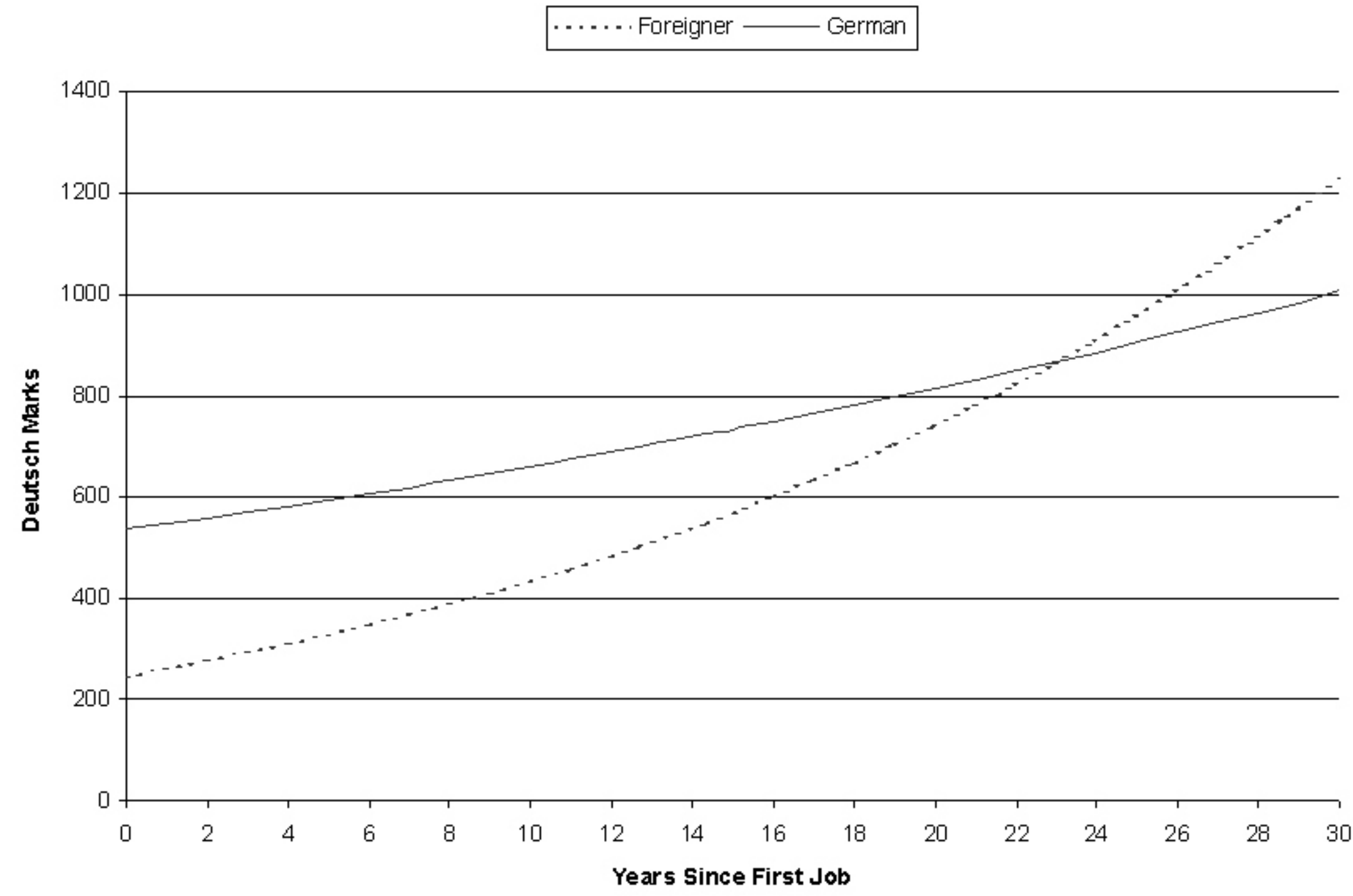




\section{IZA Discussion Papers}

\begin{tabular}{|c|c|c|c|c|}
\hline No. & Author(s) & Title & Area & Date \\
\hline 759 & E. P. Lazear & The Peter Principle: A Theory of Decline & 1 & $04 / 03$ \\
\hline 760 & E. P. Lazear & Entrepreneurship & 5 & $04 / 03$ \\
\hline 761 & E. P. Lazear & $\begin{array}{l}\text { Output-Based Pay: Incentives, Retention or } \\
\text { Sorting? }\end{array}$ & 5 & $04 / 03$ \\
\hline 762 & $\begin{array}{l}\text { M. Gerfin } \\
\text { R. E. Leu }\end{array}$ & $\begin{array}{l}\text { The Impact of In-Work Benefits on Poverty and } \\
\text { Household Labour Supply - A Simulation Study } \\
\text { for Switzerland }\end{array}$ & 3 & $04 / 03$ \\
\hline 763 & $\begin{array}{l}\text { M. Biewen } \\
\text { S. P. Jenkins }\end{array}$ & $\begin{array}{l}\text { Estimation of Generalized Entropy and Atkinson } \\
\text { Inequality Indices from Complex Survey Data }\end{array}$ & 5 & $04 / 03$ \\
\hline 764 & P. A. Puhani & $\begin{array}{l}\text { A Test of the 'Krugman Hypothesis' for the } \\
\text { United States, Britain, and Western Germany }\end{array}$ & 2 & $04 / 03$ \\
\hline 765 & W. Schnedler & $\begin{array}{l}\text { On the Prudence of Rewarding A While Hoping } \\
\text { for B }\end{array}$ & 5 & $04 / 03$ \\
\hline 766 & $\begin{array}{l}\text { D. N. F. Bell } \\
\text { R. A. Hart }\end{array}$ & $\begin{array}{l}\text { How Important Is Guaranteed or Institutionalised } \\
\text { Overtime? }\end{array}$ & 5 & $04 / 03$ \\
\hline 767 & $\begin{array}{l}\text { P. Carneiro } \\
\text { K. T. Hansen } \\
\text { J. J. Heckman }\end{array}$ & $\begin{array}{l}\text { Estimating Distributions of Treatment Effects } \\
\text { with an Application to the Returns to Schooling } \\
\text { and Measurement of the Effects of Uncertainty } \\
\text { on College Choice }\end{array}$ & 6 & $04 / 03$ \\
\hline 768 & $\begin{array}{l}\text { J. J. Heckman } \\
\text { S. Navarro-Lozano }\end{array}$ & $\begin{array}{l}\text { Using Matching, Instrumental Variables and } \\
\text { Control Functions to Estimate Economic Choice } \\
\text { Models }\end{array}$ & 6 & $04 / 03$ \\
\hline 769 & $\begin{array}{l}\text { L. Flood } \\
\text { J. Hansen } \\
\text { R. Wahlberg }\end{array}$ & $\begin{array}{l}\text { Household Labor Supply and Welfare } \\
\text { Participation in Sweden }\end{array}$ & 3 & $04 / 03$ \\
\hline 770 & A. Heitmueller & Coordination Failures in Network Migration & 1 & $04 / 03$ \\
\hline 771 & $\begin{array}{l}\text { A. Calvó-Armengol } \\
\text { Y. Zenou }\end{array}$ & $\begin{array}{l}\text { Job Matching, Social Network and } \\
\text { Word-of-Mouth Communication }\end{array}$ & 5 & $05 / 03$ \\
\hline 772 & $\begin{array}{l}\text { E. Patacchini } \\
\text { Y. Zenou }\end{array}$ & $\begin{array}{l}\text { Search Intensity, Cost of Living and Local } \\
\text { Labor Markets in Britain }\end{array}$ & 3 & $05 / 03$ \\
\hline 773 & A. Heitmueller & $\begin{array}{l}\text { Job Mobility in Britain: Are the Scots Different? } \\
\text { Evidence from the BHPS }\end{array}$ & 1 & $05 / 03$ \\
\hline 774 & $\begin{array}{l}\text { A. Constant } \\
\text { D. S. Massey }\end{array}$ & $\begin{array}{l}\text { Labor Market Segmentation and the Earnings of } \\
\text { German Guestworkers }\end{array}$ & 1 & $05 / 03$ \\
\hline
\end{tabular}

An updated list of IZA Discussion Papers is available on the center's homepage www.iza.org. 